\title{
New evidences of Holocene tectonic and volcanic activity of the western part of Lake Sevan (Armenia)
}

\author{
Ara AVAGYAN ${ }^{1, *}$, Lilit SAHAKYAN ${ }^{1}$, Khachatur MELIKSETIAN ${ }^{1}$, Arkadi KARAKHANYAN $^{1}$, \\ Vasily LAVRUSHIN ${ }^{2}$, Tatul ATALYAN ${ }^{1}$, Hayk HOVAKIMYAN ${ }^{1}$, Seda AVAGYAN ${ }^{1}$, \\ Petros TOZALAKYAN ${ }^{1}$, Evgenia SHALAEVA ${ }^{2}$, Christine CHATAINGER ${ }^{3}$, \\ Sergey SOKOLOV ${ }^{2}$, Arkadi SAHAKOV ${ }^{1}$ and Gagik ALAVERDYAN ${ }^{1}$ \\ 1 Academy of Sciences of Armenia, Institute of Geological Sciences, Baghramyan 24a, 0019 Yerevan, Armenia \\ 2 Geological Institute of the Russian Academy of Sciences (RAS), 7 Pyzhevsky, Moscow 119017, Russia \\ 3 Archeorient UMR 5133 CNRS, Maison de l'Orient et de la Mediterranee, Jean Pouilloux, 7 rue Raulin, 69365 Lyon, France
}

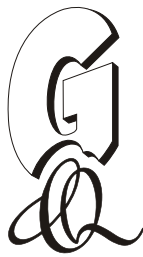

\begin{abstract}
Avagyan, A., Sahakyan, L., Meliksetian, K., Karakhanyan, A., Lavrushin, V., Atalyan, T., Hovakimyan, H., Avagyan, S., Tozalakyan, P., Shalaeva, E., Chatainger, C., Sokolov, S., Sahakov, A., Alaverdyan, G., 2020. New evidences of Holocene tectonic and volcanic activity of the western part of Lake Sevan (Armenia). Geological Quarterly, 64 (2): 288-303, doi: $10.7306 / \mathrm{gq} .1530$

The purpose of this paper is to present new data on active geological processes in the Lake Sevan Basin and to show its multidisciplinary aspects. The investigations of its structures, recent lake sediments, and lake floor gas emission allow a better understanding of the history of geological development and the recent tectonic and volcanic activity of the basin This paper summarizes underwater investigations of active geological features of Lake Sevan, undertaken for the first time in Armenia. More than 30 aligned underwater-source related gas emission points were discovered. The gas contains carbon dioxide of volcanic or volcanogenic-metamorphogenic origin and can be related to unloading of deep fluid systems. This allows defining the Noratus-Kanagegh Fault segment trace below the recent Lake Sevan floor sediments. The discovery of the subaqueous segment of active fault shows the presence of another natural hazard of lake tsunami related to possible future co-seismic rupture. The recent sediments of the northwestern Lake Sevan coastline are sandwiched between two blocky lava flows. The radiocarbon dating of bones of bovine mammals (with entire skull), found $\sim 15 \mathrm{~cm}$ from the cover of the lake sediments, suggests that the upper blocky basaltic-andesite layer can be a result of eruption younger than $\sim 3400$ years BP. About $80 \mathrm{~m}$ of the Noratus sequence sediments have been sampled for palaeomagnetic study and the age of 3.1-2.3 Ma for the lower part $(42 \mathrm{~m})$ is obtained. The upper and post-Gelasian activity of the Noratus-Kanagegh Fault is proven by a cross-cutscoria layer of $2.30 \pm 0.15 \mathrm{Ma} \mathrm{K} / \mathrm{Ar}$ age.
\end{abstract}

Key words: active fault, gas emission, lake sediments, palaeomagnetism, lake tsunami.

\section{INTRODUCTION}

The study area is situated in the central part of the Arabia-Eurasian continental collision zone and is characterized by complex geology (Fig. 1) and dense concentration of active faults (Fig. 2A). A study of intra-block active faults have a fundamental importance for accessing seismic hazards and risks particularly for small countries with relatively dense population such as the Republic of Armenia. These faults can be of relatively low and medium magnitude potential. However, the study of natural hazard becomes important, because of high population density (the population in the Sevan Basin area reaches 280,000 people in 92 communities, of which five are urban) and

\footnotetext{
* Corresponding author, e-mail: avagn1064@gmail.com Received: November 20, 2019; accepted: February 19, 2020; first published online: May 4, 2020
}

widespread land usage. The study of the area is important for the methodological point of view because of possible interaction between volcanic and tectonic activities and lake tsunami.

The active normal and oblique slip faults are well-expressed in the crest area and on the eastern slope of the Gegham Volcanic Highland (Milanovsky, 1952, 1968; Karakhanyan et al., 2004, 2016; Avagyan et al., 2005, 2010) limiting the southwestern part of Lake Sevan of volcano-tectonic origin.

The aim of the paper is to evidence recent tectonic and volcanic activity in the western part of the Lake Sevan Basin with studying the lake sediments, structures and geology, using multidisciplinary approaches including underwater investigations to shows multi-hazard aspects of the basin.

\section{GEOLOGICAL SETTING}

The middle east-Armenian Highland area is characterized by two distinct suture zones: the Northern Tethyan suture zone of Izmir-Ankara-Erzincan-Amasia-Sevan-Hakari (IAEASH), and 
the Southern Tethyan suture zone of Misis-Andirin-Bitlis-Zagros (MABZ). They formed from the closure of the Palaeotethys Ocean (northern branch of the Neotethys to the north, and the southern branch of the Neotethys to the south; e.g., Sosson et al., 2010; Rolland, 2017; Barrier et al., 2018). The closure of the northern branch and collision of the Gondwana-derived South Armenian Block (SAB correlated to the Taurides-Anatolides) with Eurasia occurred in the Late Cretaceous (e.g., Sosson et al., 2010; Rolland, 2017), and the Arabia-Eurasia (with SAB in the south) collision in the Late Eocene-Oligocene according to most authors (e.g., Homke et al., 2010; Rolland et al., 2012). The summarize articles of the geodynamic evolution of the Caucasus Mountain belt from the Paleozoic to present, and the history of Jurassic to Eocene subduction, obduction, and continent-conti-

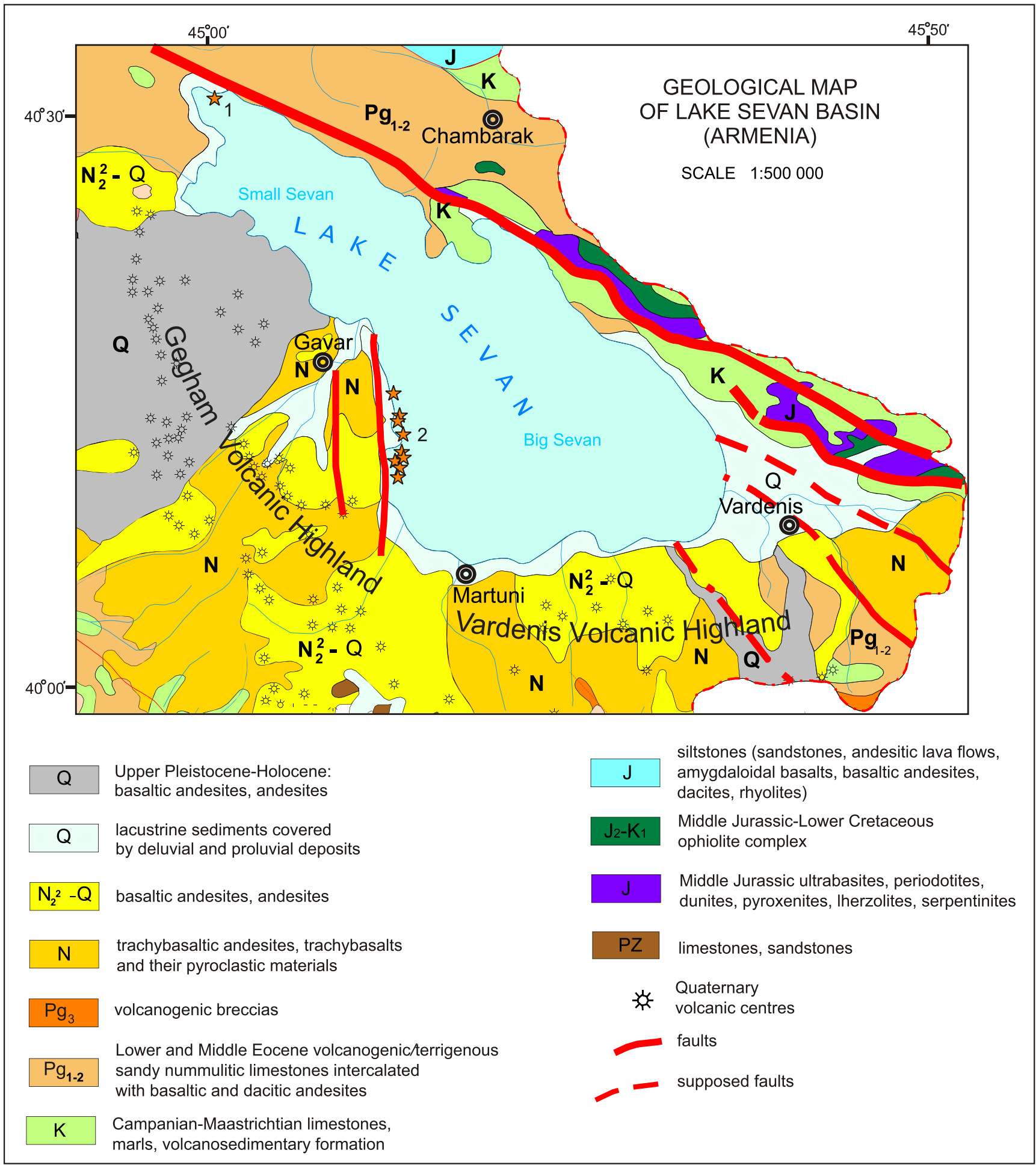

Fig. 1. Geological map of the Lake Sevan Basin (location is indicated in Fig. 2) modified from Kharazyan (2005) 


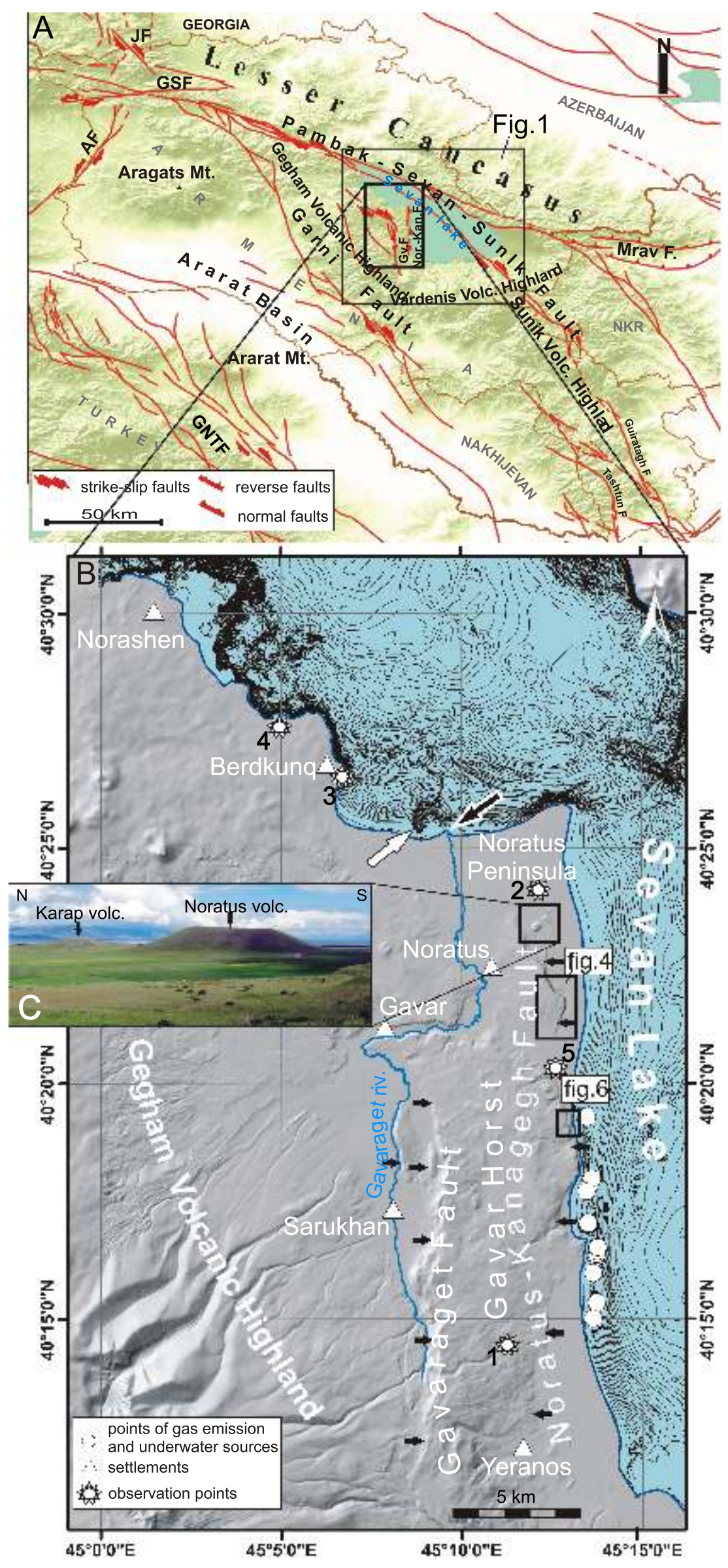

nent collision between Eurasia and Arabia is presented by Avagyan et al. (2005, 2010), Galoyan (2008), Sosson et al. (2010) and Rolland (2017), with references therein. During Eocene times, intense magmatic and volcanic phases took place to the north of the MABZ suture zone, connected with a north-dipping southern Neotethys subduction, in an extensional (back-arc) environment of orogenic belts, suggesting the Arabia-Eurasia collision after this magmatic event (Sahakyan et al., 2017).

The lowest part of the Sevan Basin is occupied by Sevan Lake divided into two sub-basins (Big and Small Sevan basins). The geological structures of the northeastern part of Lake Sevan are well-studied. Here, the Middle Jurassic and Early Cretaceous ophiolite suture zone (Sevan-Hakari) is situated to the NNE of Lake Sevan (e.g., Galoyan, 2008; Sosson et al., 2010; Asatryan et al., 2010; Avagyan, 2013) controlled by the Pambak-Sevan-Sunik active fault (Fig. 2).

Due to the southern Neotethys closure, the Sevan-Hakari ophiolitic suture zone was reactivated by some major thrusts and strike-slip faults (Avagyan et al., 2005, 2010). NW-SE compression was dominant between the Paleogene and late Early Miocene, and NE-SW compression has revealed between the Late Miocene and Quaternary (Avagyan et al., 2010).

The W, SW and S parts of the Sevan Basin are represented by the Gegham and Vardenis volcanic highlands, respectively. These volcanic systems were active since the Late Miocene (including in the Holocene) and, during the Quaternary, developed as monogenetic volcanic fields with hundreds of known volcanoes (Karapetian, 1965; Djrbashyan, 2013).

Sevan is the largest fresh water lake in the region with an area of $1240 \mathrm{~km}^{2}$, which is $\sim 4.2 \%$ of the entire area of the Republic of Armenia. Lake Sevan is situated at the elevation of $1900 \mathrm{~m}$ a.s.l., although it evolved into its present form only in the Holocene. The only passage, from where the lake water gets out from the Sevan Basin, is the headwater of the Hrazdan River. A series of volcanic episodes took place throughout the Pleistocene and into the Holocene, causing

Fig. 2A - active fault map of the Lesser Caucasus and surrounding area (modified from Philip et al., 2001; Karakhanyan et al., 2003, 2004; Avagyan et al., 2010, Avagyan, 2013); GSF - Geltarechka Sarighamich Fault, AF Akhuryan Fault, NKR - Nagorno Karabakh Republic, GNTF - Gaylatu North Tavriz Fault; B three-dimensional model of the relief and the map of Lake Sevan; C - photo of the Noratus and Karap volcanoes; the fault scarps are indicated by arrows 
damming of the river system at its NW flank and further evolution of lacustrine conditions (Aslanyan and Sayadyan, 1984).

Archaeological evidence indicates that human habitation had taken place around the shores of a lake, much reduced in size at that time. A human-induced decrease in water depth of $\sim 16$ m during the second half of the 20th century revealed Early and Late Bronze Age settlements and burial sites rich in artefacts, including wooden chariots (yielding radiocarbon dates of 3500-3630 \pm 100 years BP), near Lchashen and Norashen (Aslanyan and Sayadyan, 1984).

The active faults display high seismic activity manifested in both strong earthquakes and many smaller events (Philip et al., 2001; Karakhanyan et al., 2003, 2004; Avagyan et al., 2010, $2013,2019)$. Methane emissions and geochemical anomalies have been recorded along the active fault zones traversing the bottom of the lake (Karakhanyan et al., 2001).

During the last decade, several studies of the lake bottom were undertaken based mostly on geophysical surveys (mostly echographic) of the relief (Avagyan, 2013; Karakhanyan et al., 2016). Nevertheless, the structure of the floor of Lake Sevan appears to be crossed by active faults and their individual segments remain largely unstudied.

\section{OVERVIEW OF THE STUDY AREA}

The study area is situated in the gently inclined $\left(5-10^{\circ}\right)$ eastern slope of the central part of the Gegham Volcanic Highland (Figs. 1 and 2). Here, besides Quaternary lacustrine, alluvial, lacustrine-alluvial and volcano-sedimentary rocks of Neogene-Quaternary ages, volcanic formations (trachybasaltic andesites, trachybasalts and their pyroclastic materials) are also widespread (Kharazyan, 2005).

The main feature of this area is the existence of Neogene-Quaternary volcanism and active faults (Paffenholtz, 1948; Gabrielyan, 1963; Milanovsky, 1952, 1968; Avagyan, 2001, 2010; Karakhanyan et al., 2001, 2016; Djrbashyan et al., 2002; Karakhanyan et al., 2004; Dirbashyan, 2013). Within the study area, two active faults are known: the Gavaraget and the Noratus-Kanagegh faults (Fig. 2). Historical earthquakes of 1226 AD (Mw 6.2) and 1322 AD (Mw 6.6) are attributed to the Gavaraget Fault (Karakhanyan et al., 2016).

This study is focused on the Noratus-Kanagegh active fault zone. The fault was previously called the Sarikaya Fault (Milanovsky, 1952, 1968) and Noratus Fault (Avagyan et al., 2010; Karakhanyan et al., 2016). We used the new name to indicate fault direction and to avoid confusion with another geological fault near the Noratus Peninsula. The uplifted area we studied is restricted to two normal faults: the eastward-dipping Noratus-Kanagegh Fault and the westward-dipping Gavaraget Fault. Together, these structures may be interpreted as a horst. It is $20-25 \mathrm{~km}$ long and $4-7 \mathrm{~km}$ wide (Milanovsky, 1968; Avagyan, 2001). We name the above-mentioned horst the Gavar Horst (Fig. 2).

The kinematics of faults bounding the Gavar Horst is consistent with the E-W extension of $2.4 \pm 0.9 \mathrm{~mm} / \mathrm{y}$ velocity evidenced by GPS measurement. The extension axis traverses the Gegham Volcanic Highland and the southern part of Lake Sevan (Davtyan, 2007).
Several abandoned valleys were found on the Gavar Horst block. The phenomenon is caused by the formation of $>200 \mathrm{~m}$ high scarp of the Gavaraget Fault. It dammed and deflected water flows from the eastern slopes of the Gegham Volcanic Highland. In the Gavar city area, a temporary lake of tectonic origin was formed and described by Avagyan (2001).

The Noratus-Kanagegh Fault is $\sim 25 \pm 3 \mathrm{~km}$ long and, according to stratigraphic datasets, was active in Pleistocene and even Holocene times (Milanovsky, 1952). A cumulative vertical displacement of $100 \mathrm{~m}$ is recorded for the Noratus-Kanagegh Fault, estimated from borehole log data obtained $\sim 500$ m east of the scarp (Milanovsky, 1952).

More than $80 \mathrm{~m}$ of strata from the Noratus sequence is exposed along the Noratus-Kanagegh Fault scarp (Figs. 3 and 4). It consists of sedimentary, volcano-sedimentary and volcanic formations accumulated from the Late Miocene up to the Holocene (Milanovsky, 1953). Milanovsky (1952) subdivided the Noratus sequence into 8 units of lacustrine, alluvial, proluvial and volcanic deposits.

As mentioned earlier, the Neogene-Quaternary volcanic activity is quite typical for the investigated area (Milanovsky, 1952, 1968; Karakhanyan et al., 2001, 2016; Avagyan et al., 2001, 2010; Djrbashyan et al., 2002; Karakhanyan et al., 2004; Djrbashayn, 2013). Volcanic activity is associated with the Gegham Volcanic Highland, one of the densest clusters of individual monogenetic volcanoes in Armenia. The Gegham Volcanic Highland represents a $65 \mathrm{~km}$ long and $35 \mathrm{~km}$ wide oval zone with a NNW elongation. In total, it consists of 127 Quaternary volcanoes, located parallel to the axis of the volcanic highland, and their central (elongated) volcanic ridge in the middle. Compositionally, this volcanism varies from trachybasalts to rhyolites, while dacites are relatively rare. Most of the monogenetic vents are trachybasaltic, basaltic-trachyandesitic and trachyandesitic in composition and are characterized by Strombolian to violent Strombolian eruption types. Several rhyolitic domes exist in the eastern and central clusters of the Gegham Volcanic Highland.

Timing of volcanism within the Gegham Volcanic Highland varies from Pliocene to Holocene (Karakhanyan et al., 2003 and references therein). Dozens of extended lava flows, some of them reaching Lake Sevan, are well-known (e.g., Karakhanyan et al., 2004). In the Noratus sequence, volcanism is manifested by pyroclastic material mixed with sediments, as well as by pure pyroclastic fallout deposits. Noratus and Karap volcanoes are located on the northern flank of the Noratus-Kanagegh Fault, $0.5-1.5 \mathrm{~km}$ east of the main scarp (Fig. 2C). We can state that these volcanoes are restricted to the fault zone and, taking into account the eastward-dipping fault plane, they are genetically related to the normal kinematics, regressive erosion, and the considerable scarp height.

Milanovsky (1968) considered that the structures genetically related to the Gegham Volcanic Highland (to the west of Lake Sevan) are inherited from Eocene-Oligocene time. Based on multidisciplinary investigations, Avagyan et al. (2010) concluded that part of these structures is indeed inherited from Paleogene-Neogene times and influenced the further stress-field and structural features of the region. The Noratus-Kanagegh Fault is a recent structure in accordance with the Upper Quaternary age (Qocharyan and Shirinyan, 1978) of Noratus and Karap volcanoes. 

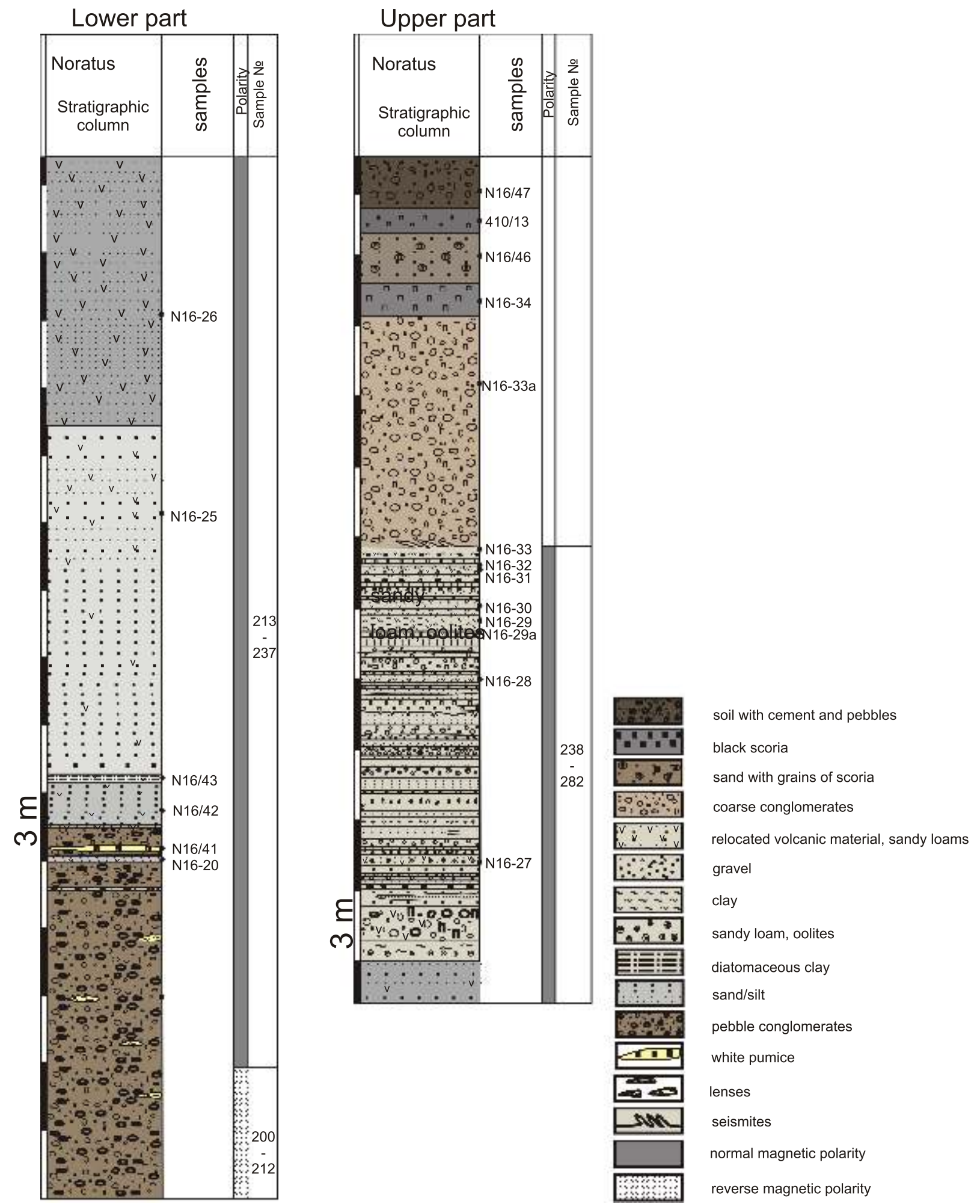

Fig. 3. Lithostratigraphic column of the Noratus area

Recent geological investigations suggest that a close relationship of the volcanic and fault activity in space and time is evident (e.g., Karakhanyan et al., 2004; Avagyan et al., 2005, 2010). The volcanic interlayers in the lake sediments accumulated by Gavaraget Fault damming are good evidence for their temporal connection (Avagyan et al., 2010).

\section{MATERIALS AND METHODS}

Nearly all geological outcrops in the SW area of Lake Sevan were investigated for the structural analysis in this study, and rock samples were analysed and dated in order to support the 


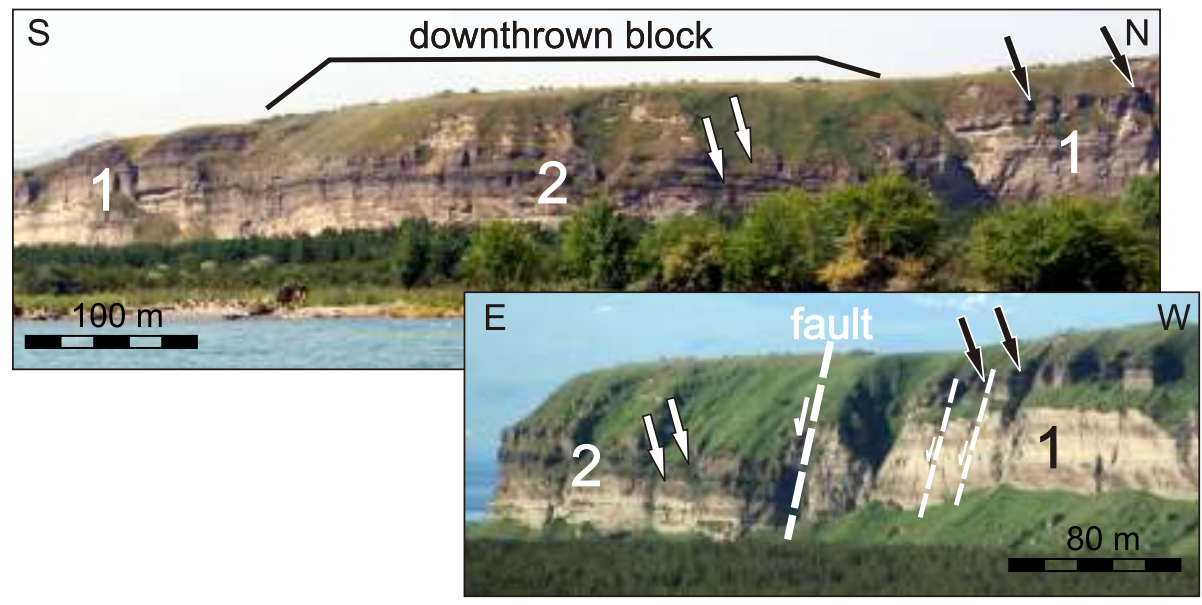

Fig. 4. Part of the Noratus-Kanagegh Fault segment

1 - lower block of normal fault; 2 - upper block of normal fault; arrows show dislocated two horizons of scoria (black arrows are on the lower block);

location of the block is shown in Figure 2

stratigraphy. Two geological stratigraphic columns were prepared based on the newly collected data and updated lithostratigraphy, taking into account both previous studies (e.g., Milanovsky, 1952, 1968) and data from the borehole near the Lake Sevan shore (Milanovsky, 1952; Balyan and Boshnaghyan, 1964). Landsat/Copernicus Digital Globe images and aerial (drone) images were used in order to generate 3D relief maps. Petrographic and mineralogical analyses were conducted in the laboratory of lithology and regional geology, whereas whole rock major elements (silica analyses) were analysed in the laboratory of chemistry at the Institute of Geological Sciences of the Republic of Armenia. Silica analyses were done according to NSAM (Research Council for analytical methods of research) instructions.

This study is based on structural and morphostructural analyses at different scales (micro- to macro-scale), petrographic studies and palaeomagnetic and isotopic $(\mathrm{K} / \mathrm{Ar})$ age-dating. K/Ar dates of volcanic rocks were obtained at the Institute of Geology of Ore Deposits, Petrography, Mineralogy and Geochemistry of the Russian Academy of Sciences (IGEM RAS). The laboratory used the constants $\lambda \mathrm{e}=0.581 \times 10^{-10} \mathrm{a}^{-1}$, $\lambda \beta=4 \times 962 \times 10^{-10} \mathrm{a}^{-1},{ }^{40} \mathrm{~K} / \mathrm{K}=1.167 \times 10^{-4}$. The final errors were calculated as $\pm 2 \mathrm{~s}$. Radiocarbon dating were obtained and calibrated in Poznań Radiocarbon Laboratory (Poland) and in Laboratory of Beta Analytic Radiocarbon 406 Dating, Florida (USA). For determination of remanent magnetic polarity, we collected oriented samples from silt, sand, diatomaceous clay, and volcanic material. All samples were demagnetized using the alternating field up to $90 \mathrm{mT}$. Demagnetization of samples and the measurement of natural remanent magnetization (NRM) were performed at the Palaeomagnetic Laboratory of the Institute of Physics of the Earth of the RAS, Moscow, using a 2G Enterprise cryogenic SQUID-magnetometer and the standard technique.

The underwater active tectonic investigations of Lake Sevan were conducted in cooperation with "Armenian Center of Diving and Subaqueous Research" (CARPS: French acronym). CARPS has provided the entire material-technical base, which includes: a motor boat, a transporting cart, a sonar, a charging compressor, and diving materials. CARPS also provided four divers of international rank (K. Tulumjyan, S. Kojoyan, V. Melkonyan and A. Avagyan).
The gas emission was localized by a Humminbird $898 \mathrm{c}$ SI Combo SONAR equipped with GPS (Humminbird Electronics). Gas bubbles were collected in plastic flasks by divers and used for analyses. The preliminary compositions of gas samples were determined with a Biogas 5000 gas analyzer [Geotechnical Instruments (UK) Limited]. The device allows measuring methane, oxygen, carbon dioxide, and nitrogen content.

The chemical composition of MV gases was determined at Geological Institute, Russian Academy of Sciences (GIN, RAS), using a Crystal 5000 gas chromatograph by absolute calibration for each component using standard gas mixtures. The error in the determination of each component does not exceed 0.2 vol.\%. To determine the carbon isotopic composition in gases $\left(\mathrm{CO}_{2}\right.$ and $\left.\mathrm{CH}_{4}\right)$, a Thermoelectron Corporation equipment complex was used, including a mass spectrometer Delta $\checkmark$ Advantage and a GC gas chromatograph. Samples and standards were decomposed with $100 \%$ phosphoric acid at $50^{\circ} \mathrm{C}$ in a helium atmosphere and measured in a conflow mode. $\delta^{13} \mathrm{C}$ values are reported relative to $\mathrm{V}$-PDB standard. The accuracy of determination of $\delta^{13} \mathrm{C}$ made up $\pm 0.2 \%$. The $\mathrm{C}$ isotope studies were performed at GIN RAS (Moscow).

The chemical and trace elements of the obsidian tool are analysed by the LA-ICP-MS method in laboratory of CNRS "IRAMAT" d'Orlean (France).

\section{NEW RESULTS}

In order to define the palaeoenvironmental setting, $80 \mathrm{~m}$ of sedimentary rocks from the Noratus section were described in detail, including their grain size, textures and sedimentary structures. The lower part of the section is composed of $\sim 18 \mathrm{~m}$ thick Upper Miocene (?)-Pliocene conglomerates. The conglomerates are poorly to moderately sorted, clast- to matrix-supported, and consist of pebbles and cobbles in a pebbly sandstone matrix (Fig. 3). Normally graded clasts consist of basalts, andesites and rare tuff pebbles, brought mostly from the underlying Miocene volcanic sequences. These deposits bear a record of limited turbulence and sorting during transformation of gravely debris flows. Thin interbeds of sandstone are rare and discontinuous. The upper part of this conglomerate unit displays lens of 
K-Ar ages of samples from the SW coast of Lake Sevan, Noratus area (Armenia*)

\begin{tabular}{|c|c|c|c|c|c|c|c|}
\hline Sample No & Location & Coordinates & Rocks & $\mathrm{K}, \% \pm \sigma$ & $\begin{array}{c}{ }^{40} \mathrm{Ar}_{\text {rad }}(\mathrm{ng} / \mathrm{g}) \\
\pm \sigma\end{array}$ & $\begin{array}{c}{ }^{40} \mathrm{Ar} \text { atm, \% } \\
\text { (in sample) }\end{array}$ & $\begin{array}{c}\text { Age, Ma } \\
\pm 2 \sigma\end{array}$ \\
\hline $410 / 13$ & $\begin{array}{c}\text { v. Noratus, S } \\
410, \mathrm{H}=2005\end{array}$ & $\begin{array}{c}\mathrm{N} 40.369983^{\circ} \\
\mathrm{E}^{\circ} 5.205217^{\circ}\end{array}$ & Black tuff $\mathrm{Q}_{1}(?)$ & $2.21 \pm 0.03$ & $0.354 \pm 0.009$ & 89.3 & $2.30 \pm 0.15$ \\
\hline
\end{tabular}

* - dated by V.A. Lebedev (Institute of Geology of Ore Deposits, Petrography, Mineralogy and Geochemistry of Russian Academy of Sciences)

white volcanic pumice deposit (N16/41). The $\mathrm{SiO}_{2}$ content of the pumice (67.36 wt.\%, N16/41, Fig. 3) reveals dacite composition with total alkali of $6.60 \%\left(\mathrm{Na}_{2} \mathrm{O}=2.50 \% ; \mathrm{K}_{2} \mathrm{O}=4.10 \%\right)$, i.e. subalkaline series.

Due to the lack of fossils, it is difficult to identify whether the conglomerates are lacustrine or fluvial, but taking into account the conformable contact with the overlying thick sandstones and diatomaceous clay, and the lack of palaeosoil, we ascribe it to subaqueous debris flows in a shoreline setting. The conglomerates are covered with sandy loams (N16/23) and diatomaceous clay (N16/43) with volcaniclastic material input. The thickness of the sandstone unit is $\sim 10 \mathrm{~m}$. These are well-bedded and well-sorted deposits with stratification and normal grading from coarse-grained sandstone to fine sand. The third unit $(\sim 12 \mathrm{~m})$ is represented by well-stratified sandy loam, clay and, clayey diatomite layers with conglomerate interbeds. We observe a wide range of oolitic textures indicating a high-energy shallow environment of flood-tidal-delta, or isolated settings such as a detached shoal. The conglomerate layers contain pumice fragments. Soft-sediment deformation and liquefaction (N16-33) features, related to tectonic (seismic) activity, are observed. The upper parts of the conglomerate contain pebbles and pumice fragments that are overlain by two black scoria layers (N16-34, 410/13). The silica content of the upper scoria layer is $56.88 \mathrm{wt} \%$, and the total alkali content is $5.60 \mathrm{wt} . \%$ $\left(\mathrm{Na}_{2} \mathrm{O}=3.60\right.$ wt. \%; $\mathrm{K}_{2} \mathrm{O}=2.00$ wt.\%). Between these two layers we found reworked sand with scoria fragments. This sequence is covered with palaeosoil which contains pebbles.

In the vicinity of the Noratus-Kanagegh Fault, a $\sim 20 \mathrm{~m}$ downthrown block is preserved, $650 \mathrm{~m}$ in length and $250 \mathrm{~m}$ in width (Fig. 4). Its layers are dipping 11 to $18^{\circ}$ to the $\mathrm{W}$ i.e., greater than the nearly horizontal ones of the footwall. This indicates that the fault plane has a listric shape.

The normal displacement is clearly outlined by the two black scoria layers (indicated by black and white arrows in Fig. 4), which were also mentioned by Milanovsky (1960). One sample taken from the upper scoria layer yields a K/Ar age of 2.30 $\pm 0.15 \mathrm{Ma}$ (Table 1) corresponding to the Gelasian. This means that the fault was active in both late and post-Gelasian time.

\section{PALAEOMAGNEITC STUDIES}

An $\sim 42 \mathrm{~m}$ portion of the Noratus sedimentary sequence (the footwall) has been sampled for palaeomagnetic study (Fig. 3). Ninety-five samples were collected. As a whole the lowermost $5 \mathrm{~m}$ of the outcrop (matrix of pebble conglomerates) showed reverse magnetic polarity (10 samples of 13 are reverse). The rest $38 \mathrm{~m}$ of the sequence has normal magnetic polarity (83 of 85 samples are normal). Taking into account that the layer of black scoria, which rests $3 \mathrm{~m}$ above the sampled sediments, has a K-Ar age of $2.30 \pm 0.15 \mathrm{Ma}$, we attribute the lower part of the pebbly conglomerates with reverse polarity to the Kaena event, and the rest of the portion with normal polarity to the upper part of the Gauss epoch. Thus, the age of the sequence is between 3.1-2.3 Ma.

\section{RECENT DEFORMATION}

At the northern flank of the Noratus-Kanagegh Fault, a Holocene deformation is evidenced in recent Lake Sevan sediments (Fig. 5 and Fig. 2: asterisk 2). The fault plane is sealed by the accumulation of sediments a (Fig. 5B), most likely formed during the artificial decrease of the lake level since 1933. The outcrop clearly shows that the origin of the observed normal fault is not tectonic and it is of seismogravitational origin.

About $7 \mathrm{~km}$ to the SSE from the village of Noratus, another downthrown block, $400 \mathrm{~m}$ long and $100 \mathrm{~m}$ wide, is preserved (Fig. 6A). The fault kinematics is well manifested on the rupture plane onthe south flank of the displaced block (Fig. 6D). According to the geological map of Karapetyan et al. (2011), the fault cuts through an Upper Pliocene lava flow.

In the graben structure (Fig. 6B) the remains of an ancient settlement show seismogenic deformations. They are particularly well-evident from the different inclinations of stelas (Fig. 6C).

To see the rupture in stratigraphy, a single slot type of trench was cut through the $\mathrm{N}-\mathrm{S}$-trending fault scarp (Fig. 7). The observed fault planes dip $82^{\circ} \mathrm{W}$. A minimum of $1.5 \mathrm{~m}$ of vertical displacement is observed in the trench. The event occurred between $1951 \pm 75$ cal BC and $376 \pm 53$ cal AD (dated and calibrated in Poznań Radiocarbon Laboratory). The reverse kinematics is apparent, developed and guided by a pre-existing fissure near the surface. In reality, the fault is of normal kinematics and the common dip is to the east.

Along one of the abandoned valleys of the Gavar Horst, $\sim 3.5 \mathrm{~km}$ north from the village of Eranos and $\sim 8 \mathrm{~km}$ SSW from trench site (Fig. 6), an archaeological complex is located (Fig. 2B: asterisk 1 and Fig. 8). The giant block walls and an artificial dam or a bridge can be identified. Samples for radiocarbon dating were taken below a fallen block (Fig. 8C). An age of 166 \pm 80 cal $A D$ is obtained from the sediments below the block clearly associated with the man-made wall (Fig. 8C). These ages fit well with the obtained timing of the seismic event as revealed by the trenching. Assuming that the discussed block is fallen as a consequence of an earthquake, we can consider that the rupture observed in the trench is of tectonic origin.

\section{ORIGIN OF PEBBLES IN THE CRATER OF NORATUS VOLCANO}

Two Quaternary volcanic centres are located in the Noratus Peninsula near the study area, namely Noratus and Karap (Fig. 


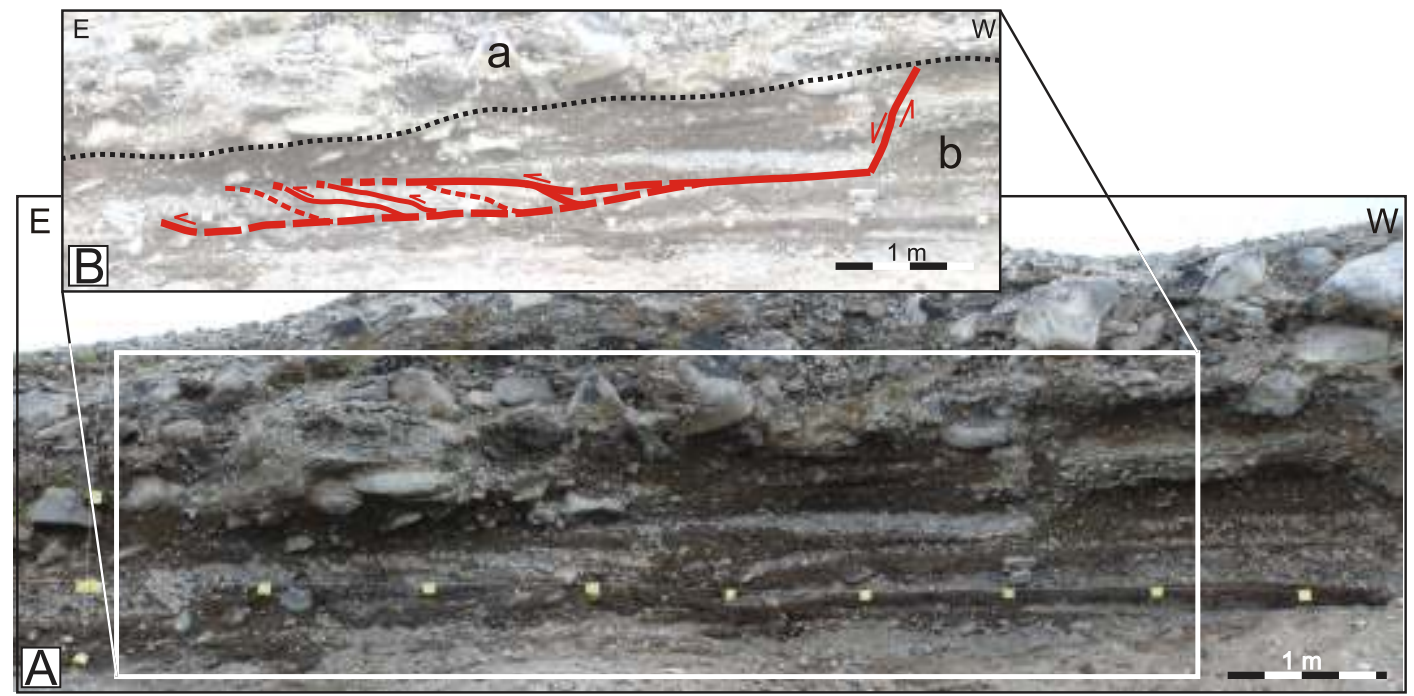

Fig. 5. Seismogenic deformations in the recent Lake Sevan sediments

A - field photograph of the outcrop; B - interpretation, seismogravitational deformation in the upper part of layer b sealed by sediments a; location is shown (by asterisk 2) in Figure 2B
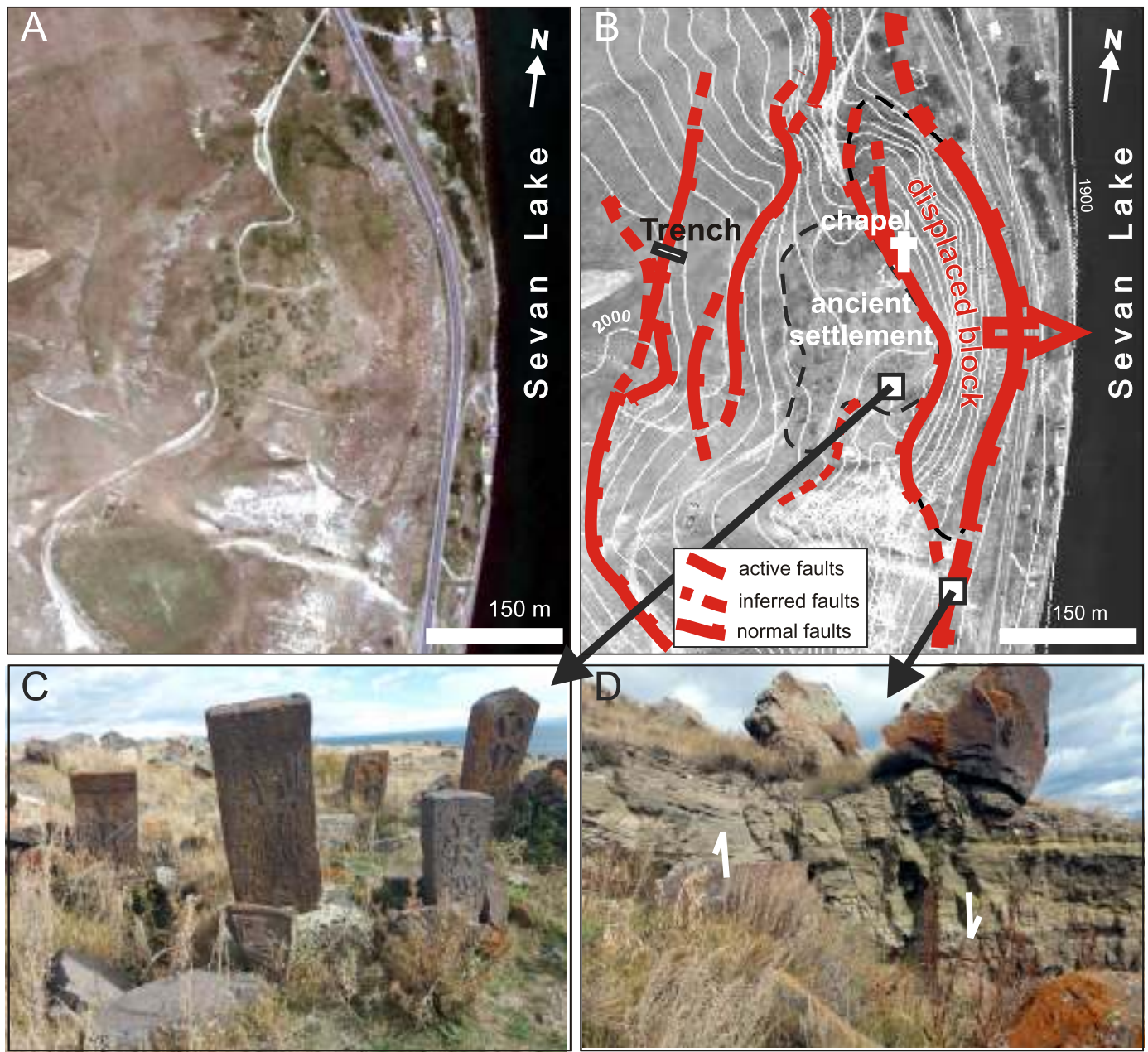

Fig. 6A - graben structure on a satellite image $\sim 7 \mathrm{~km}$ to the SSE from the village of Noratus (locations indicated in Fig. 2); B - interpretation of the structures; C - seismogenic deformations evidenced from different inclinations of stelas; D - normal fault planes south of the displaced block, the arrows indicate the blocks movements 


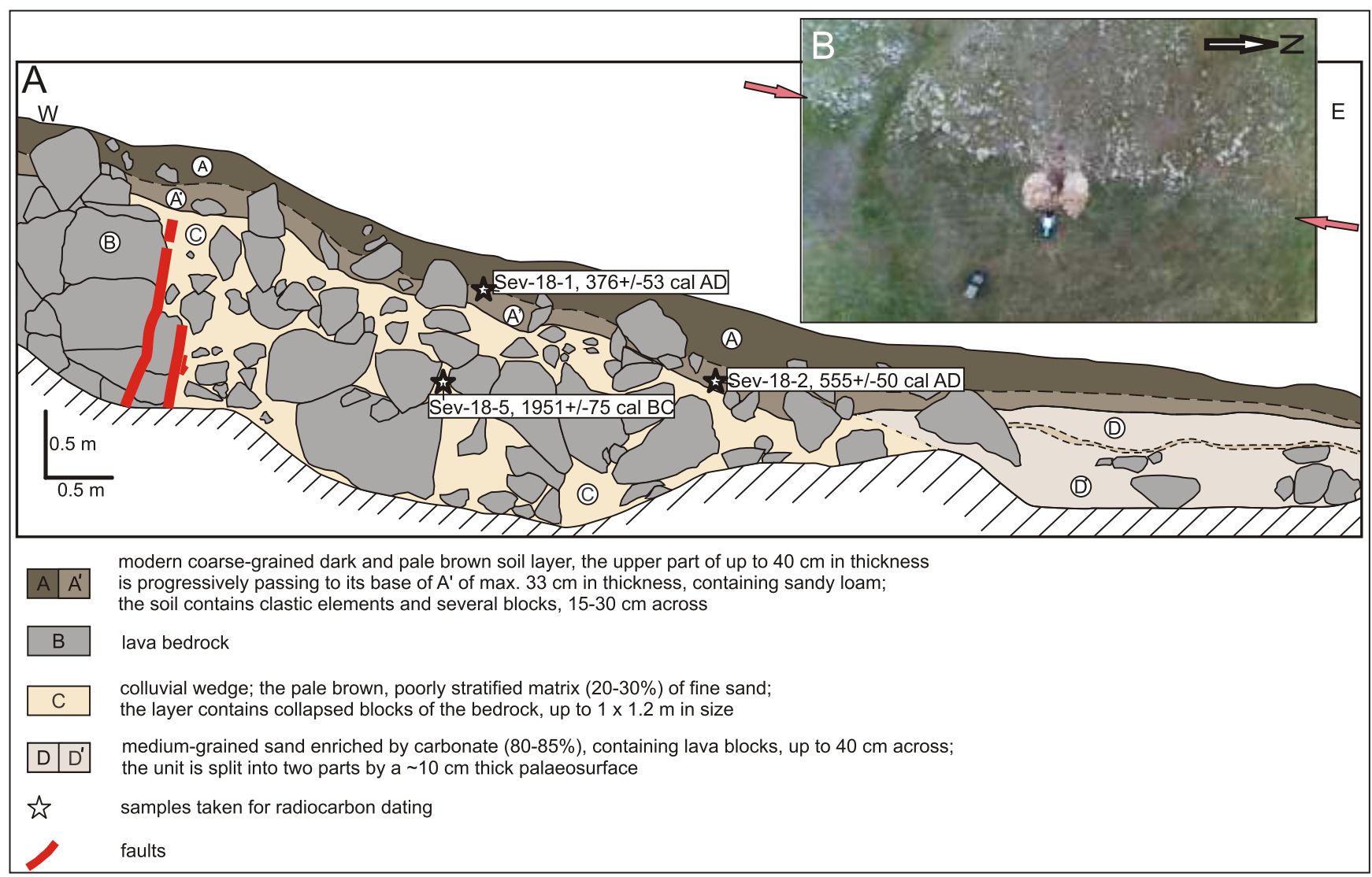

Fig. 7A - cross-section of a palaeoseismological trench (see Figure 6 for location); B - drone image of the trench

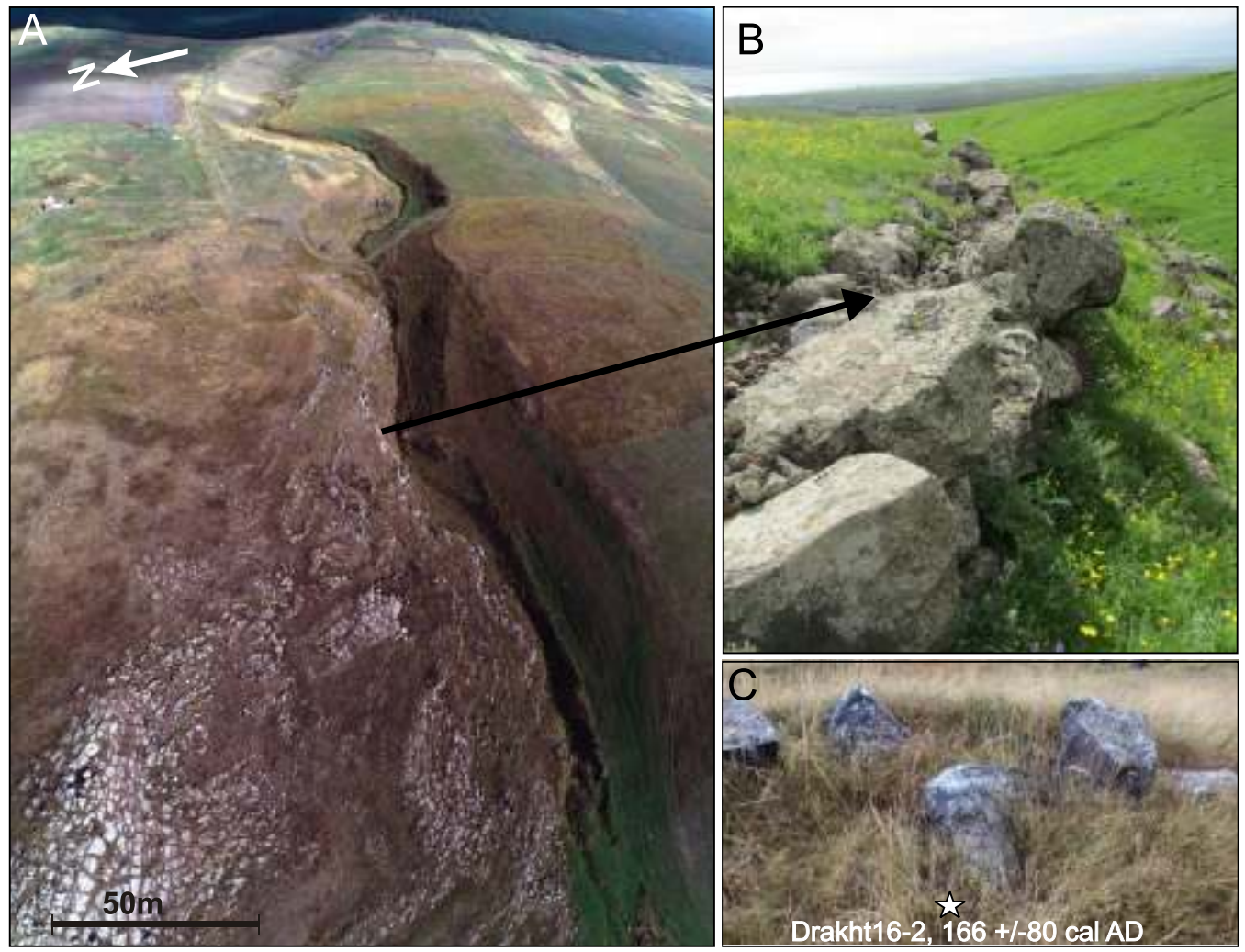

Fig. 8A - aerial photography (drone) of the tectonically abandoned valley (observation point 1, Fig. 2); B - wall destroyed by man; C, D - radiocarbon dating of sediments below fallen blocks 
2C). The diameter of the base of Noratus volcano is $\sim 460 \mathrm{~m}$, its relative height from the base is $\sim 39 \mathrm{~m}$, and the crater diameter is $\sim 150 \mathrm{~m}$. Karap volcano is a much smaller eroded cinder cone, partly buried under the Lake Sevan sediments. The diameter of the cone is $\sim 160 \mathrm{~m}$, its relative height $\sim 11 \mathrm{~m}$, and the crater is $34 \mathrm{~m}$ in diameter. Well-rounded pebbles of 10 to $15 \mathrm{~cm}$ in diameter observed in the crater of Noratus volcano (Fig. 2C) and on its slopes are the subject of scientific debate.

According to Paffenholtz (1946) and Milanovsky (1953) the presence of pebbles is related to the evolution of the volcanic structure and specifically to the process when the magma passed through the Noratus sedimentary pebble units. According to Karapetian (1965), the pebbles in the crater of Noratus volcano indicate that Noratus and the neighbouring Karap volcano (Fig. 2) were covered by Lake Sevan. This hypothesis is supported also by Qocharyan and Shirinyan (1978). Karakhanyan et al. (2016) suggested that in Lake Sevan, especially in Big Lake Sevan (southern part), the high water waves associated with the fault and the landslide activity may result in accumulation of tsunami sediments on the shoreline.

Our investigations show that pebbles are absent at the summit of Karap volcano, in spite of the fact that its top is $\sim 23 \mathrm{~m}$ lower compared to the Noratus crater summit, while Karap volcano is between Noratus volcano and the Lake Sevan shoreline. There are no pebbles inside the Noratus volcanic rock outcrops, as already acknowledged by Karapetian (1965). This author also noticed about the archaeological monument on the Noratus crater slopes. Fortress wall of $\sim 3 \mathrm{~m}$ thickness is observed along the perimeter of the Noratus crater. We also noticed evidence for the presence of artificial structures at the bottom of the crater. It is noteworthy that the quantity of pebbles increases along the old road to the crater. Based on all these ob- servations, we consider that the pebbles in the crater are related to the ancient human occupation and activity.

During the last several years, many new outcrops appeared due to water abrasion related to the increasing water levels in Lake Sevan. An interesting stratigraphic sequence is observed on the lake shore near the village of Berdkunk (in Fig. 1B: asterisk 3 and Fig. 9). Here, a 0.8-1.0 m thick light to dark grey sandy layer is sandwiched between lava boulders. The upper one is composed of angular lava boulders of basaltic andesite and forms a $0.5-0.8 \mathrm{~m}$ thick layer. There are mollusc shells in all sand levels with different quantity. Molluscs of the families Lymnaeidae, Planorbidae and Pisidiidae were observed (Arutunova et al., 2011). On top of the sandy layer, a carbonate crust is formed. Similar stratigraphic sequences are examined by Sayadyan (2009) and Karakhanyan et al. (2004) 2.5 km to the $\mathrm{NW}$, along the road $\left(40.462489^{\circ} \mathrm{N}, 45.082956^{\circ} \mathrm{E}\right)$ near the village of Lchap (Fig. 2B: asterisk 4). At this site, the volcanic activity resulted in lava flows between $7860 \pm 100-2090 \pm 70$ yr BP, covering the Lake Sevan sediments (Karakhanyan et al., 2004). Our investigations give further insights and are based on more accurate data. About $15 \mathrm{~cm}$ from the upper limit of the lake sediments, bones of bovine mammals (with entire skull) have been found (Fig. 9B). Radiocarbon $\left(\mathrm{C}^{14}\right)$ dating of the bones (Laboratory of Beta Analytic Radiocarbon Dating) reveals an age of 3460 \pm 40 BP corresponding to $1890-1680$ BC (2 sigma).

One piece of obsidian tool was also discovered together with the mammal bones, suggesting that the animal was probably hunted by man (Fig. 9C). The chemical and trace element analysis of the obsidian tool shows that it is from Geghasar volcano situated $\sim 30 \mathrm{~km}$ from the outcrop and in the Gegham Volcanic Highland.

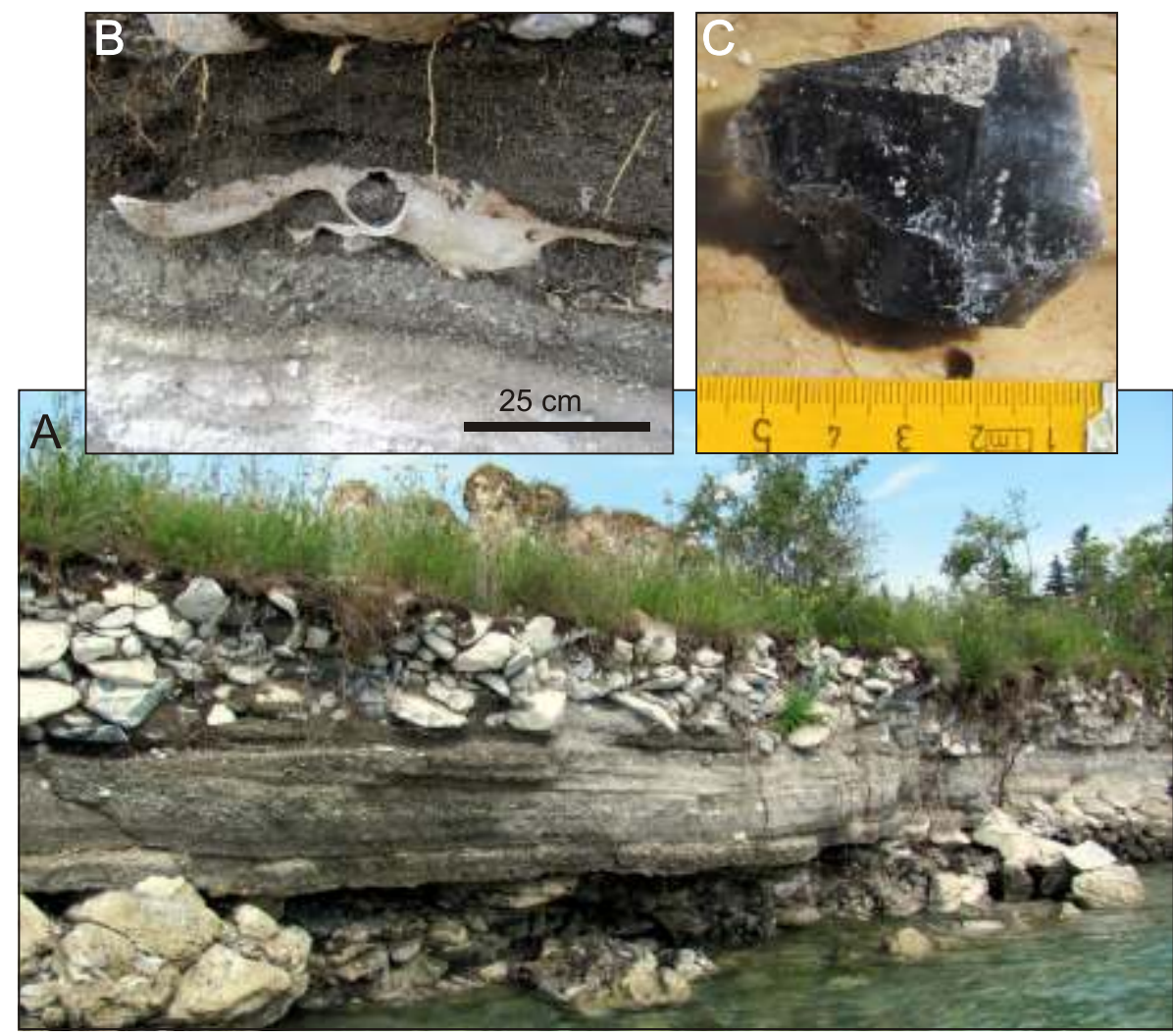

Fig. 9A - outcrops near Berdkunk village; 
Thus, the similarity of stratigraphic position in the vicinity of the site indicates that the upper blocky lava flow can be as young as $\sim 3400$ years BP. This age fits well with the interval based on abundant finds of Early Bronze age pottery (IV-III Mil, $\mathrm{BC}$ ) in lake sediments that are covered by the same lava flows (Sayadyan, 2009; Karakhanyan et al., 2016).

\section{SEISMITES AND LIQUEFACTIONS}

In the territory of the Republic of Armenia, there were no complex investigations related to seismites and liquefactions. They must be manifested in the Ararat, Shirak and Sevan sedimentary basins situated in the seismically active zone. Historical liquefaction for the 1840 Ararat strong earthquake is described by Stepanyan (1964). In the Sevan Basin, a preliminary description about liquefaction has been provided by M. Sosson and A. Avagyan (Avagyan, 2013) and Korzhenkov et al. (2014).

In the area indicated by asterisk 5 in Figure 2B, Milanovsky (1953) described microdislocations, diapiric folds $\sim 1-1.5 \mathrm{~m}$ long, which were formed in the clayey sands. According to this author, such features develop in sediments when they slided slowly over the lake floor. Our investigation shows that this interpretation cannot explain all deformation styles and textures observed at various levels $>6 \mathrm{~m}$ of the sandy layer outcropping at the base of the section (Fig. $10 \mathrm{~A}$ ). Convulations and injections of various sizes are observed, some of them E-W striking. Above the described sandy layer, two additional layers are observed. The lower one consists of coarse-grained sand and is yellowish in colour as a result of Fe oxidation. There are seismites of smaller size in both layers (Fig. 10B, C). Some of them have a clear mushroom shape. These features are of seismic origin and correspond to two or three earthquakes of $\mathrm{Mw}>5$, with the first being of the strongest intensity.

Liesegang rings are observed as well, and interpreted as resulting from percolation of groundwater down through the already deposited sandstone, and formed after chemical segregation of iron oxides and other minerals. The top of the section is covered by trachyandesites (Fig. 10) with the silica content of 60.9 wt.\% and the total alkali of 8 wt.\%.

\section{UNDERWATER STUDIES}

Some valuable data of underwater research from the lower basin of the Gavaraget River were received: it was stated that the actual river estuary is not situated in the continuation of the underwater valley (shown by black and white arrows in Fig. 2B). The land area of the actual river estuary is a cumulative coastal area, where the erosional valley is not reflected in the volcanic bedrock. The existence of the underwater bedrock valley has been confirmed by subaqueous research (dives). The valley continues at least down to $35 \mathrm{~m}$ depth. It can be assumed that the lake level during erosional activity was $\sim 35 \mathrm{~m}$ lower and a rapid rise of the water level occurred after damming of the Hrazdan River due to volcanic activity. A similar value (30-35 m) has been obtained by Vardanyants (1948) based on analyses of distribution of Bronze age graves on the lake shore after the artificial drop of the Lake Sevan water levels. Therefore, during the above discussed erosional activity, the shallow Big Lake Sevan (south of Noratus Peninsula) did not existed and the lake formed in its current borders only recently and after the erosion of volcanic rocks of the eastern cluster of the Gegham Volcanic Highland by the old Gavaraget River took place. According to Karakhanyan et al. (2004), the age of the eastern volcanic cluster of the Gegham Volcanic Highland is of post-Würm glacial age, indicating the Upper Pleistocene epoch.

In some places, the Noratus-Kanagegh Fault is near the coastline of Lake Sevan. Taking into account the fault plane dipping toward the lake and the regressive weathering of the fault scarp, we can suggest that in some sections the fault trace can be placed in the shallow underwater part of Lake Sevan (Fig. $10 \mathrm{D})$, where it is covered by recent lake sediments.

In a borehole near Noratus village the groundwater with the composition close to lake water is recovered in a pebble-conglomerate horizon at a depth of $84 \mathrm{~m}$ (Balyan and Boshnaghyan, 1964). The pebble-conglomerate horizon is situated between non-permeable clay and thick volcano-sedimentary layers. We assume that the Gavar Horst underground water flows over the non-permeable layer up to the Noratus-Kanagegh Fault segment plane that serves as a partial barrier for its circulation. Consequently, the underground water could at least partly get to the surface through the fault planes as shown in Figure 10D. It is possible that there are other parallel segments further to the east, as indicated by Karakhanyan et al. (2016).

More than three dozen points of underwater sources and gas emissions were identified linearly striking north-south over $>8$ km (Fig. 1: asterisk 2; Figs. 2B and 11). In some places, there were numerous emission points (Fig. 11C, D). In some cases, gas emission is observed at the surface with the size of 3.5 to $2 \mathrm{~m}$ (Fig. 11D). Sometimes, the emission is so powerful that it forms craters in the sand with diameters that can reach $0.9 \mathrm{~m}$ (Fig. 11B). It is important to note that the water can partly be not vertically outflow through colluvium and lake sediments, whereas the gases tend to flow out vertically.

The study of the emitted gas and water composition is important for understanding the subsoil geochemical composition and ecological interactions. It should be noted that the sample is an odorless and colourless gas mixture. More delicate analyses were conduced with a gas chromatograph and did not reveal methane or other gases. Low oxygen and nitrogen content (Table 2) of the emitted gasses are interpreted to indicate the absence of admixture of atmospheric gases.

In 2018, we conducted underwater sampling of the gases released at three points from bottom sediments of Lake Sevan (Table 2). Two of them are located near the SW shore of the lake and characterized gas emissions recorded along the strike of the Noratus-Kanagegh Fault (Fig. 1: asterisk 2 and Fig. 2B). The third sample was taken near the NE side of Small Sevan Lake in a zone of the active Pambak-Sevan-Sunik Fault (PSSF) (Fig. 1: asterisk 1). Earlier, an assumption was made based on data from methane emissions from the surface of Lake Sevan about the release of methane from the fault zone at the lake bottom (Karakhanyan et al., 2001). In 2017-2018, using a sonar, we recorded the emission of gases, mainly methane, from the PSSF active zone at the floor of Small Lake Sevan (Fig. 1: asterisk 1; Karakhanyan et al., 2018). We repeated the measurement at the same place in September 2018 and recovered water and gas samples with dives down to a depth of $42.5 \mathrm{~m}$. The depth of gas emissions on the SW shore (Noratus-Kanagegh Fault zone) varied from $30 \mathrm{~cm}$ to $3 \mathrm{~m}$. The composition of the gas samples from NE and SW shores of the lake differed dramatically. The southwestern gas emissions were represented by almost pure carbon dioxide (up to $96 \%$ ) with a small admixture of nitrogen (up to $4.5 \%$ ) and methane $(<0.05 \%)$ among other gases (Table 2). In contrast to that, methane (75.6\%) and nitrogen $(21 \%)$ prevailed in gas emitters in the NE shore. Here, the concentration of $\mathrm{CO}_{2}$ made up only $2.5 \%$. 


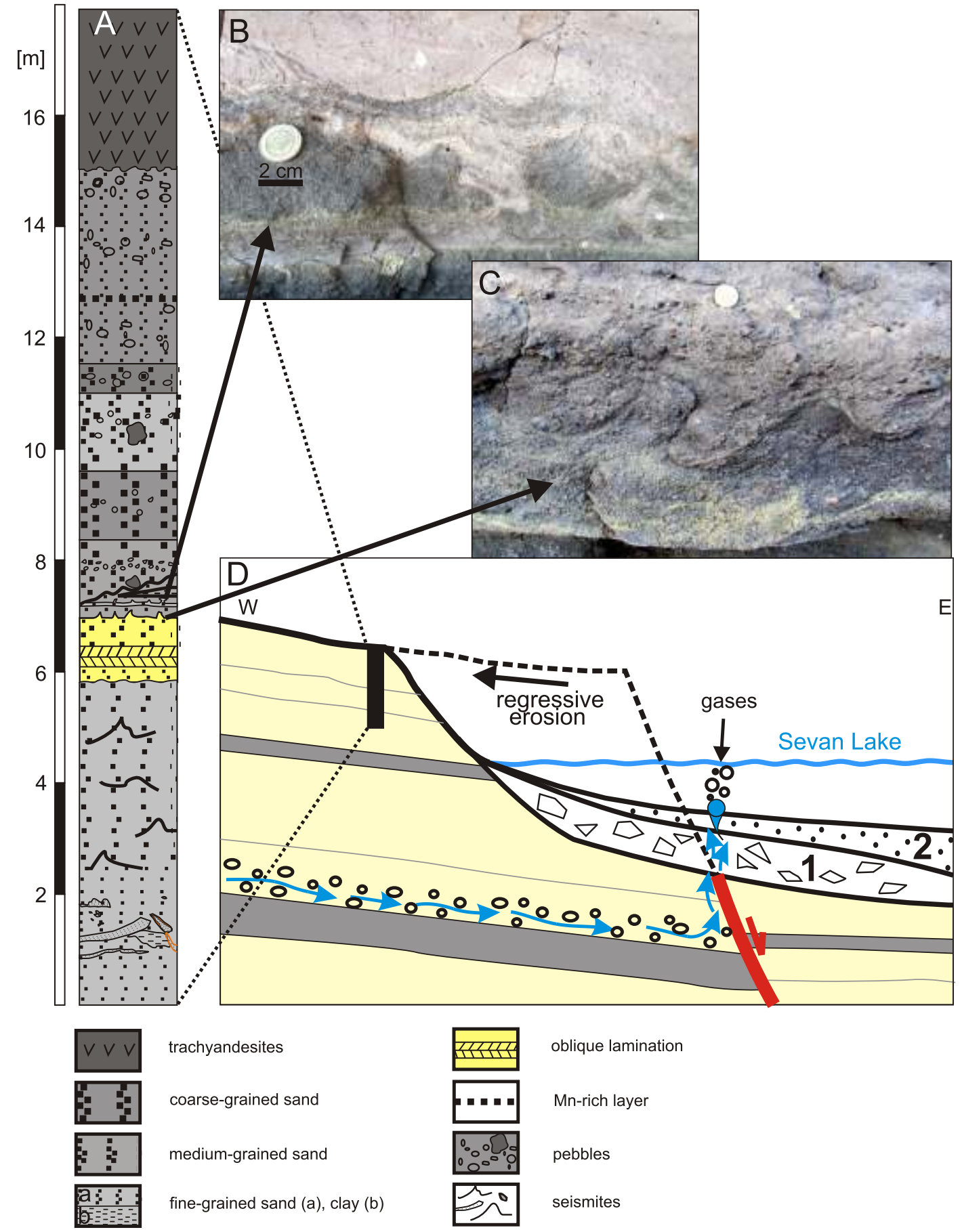

Fig. 10A - lithostratigraphic column of the site indicated by asterisk 2 in Figure 1; B, C - photos of seismites; D - schematic cross-section of the water sources and gas emission in the Kanagegh area (1 - colluvium, 2 - sand); location is shown by asterisk 5 in Figure 1

In order to understand the nature of studied gas emanations, isotopic composition of carbon in the gases was analysed. Results demonstrate that methane is characterized by low $\delta^{13} \mathrm{C}$ in $\mathrm{CH}_{4}\left(-67.7 \%\right.$ ). Almost equal low $\delta^{13} \mathrm{C}$ values are observed in the accompanying $\mathrm{CO}_{2}(-49.1 \% \circ)$. Such low $\delta^{13} \mathrm{C}$ values are indicative of biogenic origin of gases: methane is a product of the microbial decomposition of organic residues, and $\mathrm{CO}_{2}$ is formed, most likely, during the microbial oxidation of $\mathrm{CH}_{4}$. These gases are associated with nitrogen showing $\delta^{15} \mathrm{~N}$
$\left(\mathrm{N}_{2}\right)=-0.6 \%$, which is only slightly distinguishable from the corresponding value in atmospheric air $\left[\delta_{15} \mathrm{~N}\left(\mathrm{~N}_{2}\right)=0 \%\right.$ o]. Probably, about a zero value of $\delta^{15} \mathrm{~N}\left(\mathrm{~N}_{2}\right)$ reflects the early diagenetic genesis of methane in this sample (it is formed in the upper layer of lake sediments rich in organics).

In terms of isotopic characteristics, almost the same $\mathrm{C}$ and $\mathrm{N}$ gases were collected by us from the bottom sediments of the small lake located in the crater of the volcano Armagan in the eastern part of the Gegham Volcanic Highland (Table 2). There 


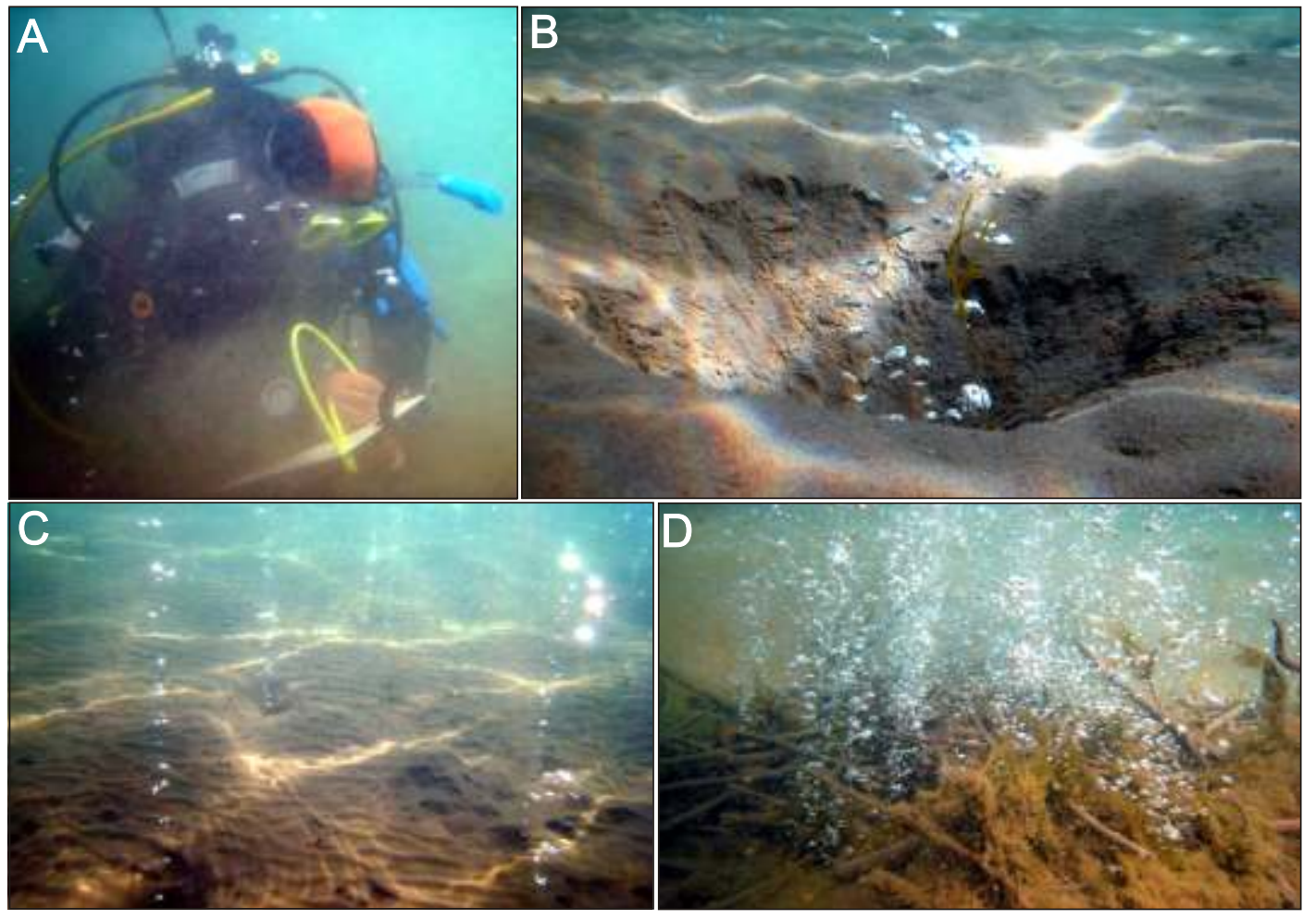

Fig. 11. Underwater photographs

A - a diver-geologist is recording the observation in a special notebook, $\mathrm{B}-\mathrm{D}-$ emission of gases in different volumes

were no signs of concentrated unloading of gases (they started to stand out intensely when mixing a gas-saturated silt layer lying on the bottom of the lake).

The emissions from the southwestern part of Lake Sevan, along segments of the Noratus-Kanagegh Fault, sharply differ from those studied in the NE. For example, they have high $\delta^{13} \mathrm{C}$ values in $\mathrm{CO}_{2}\left(-0.9\right.$ and $-1.4 \%$ ). According to the $\delta^{13} \mathrm{C}$ and $\mathrm{N}$ in $\mathrm{N}_{2}$, the detected $\mathrm{CO}_{2}$ are close to analogues of mineral spring sources that we analysed on the Lake Sevan shores (Shahinyan et al., 2019; Table 2). All of these are associated with either young volcanic centres or large active fault systems.

It is also important to note that the mineral water and associated $\mathrm{CO}_{2}$ emissions studied by us near the southwestern shore of Lake Sevan were so powerful that they even influenced the $\mathrm{pH}$ value of lake waters in the coastal zone. Usually, the water of Lake Sevan is characterized by slightly alkaline $\mathrm{pH}$ (8.8). However, near the southwestern shore, the $\mathrm{pH}$ value was significantly lower - up to 7.34, and we assume that this change is related to a massive inflow of mineral waters from segments of the Noratus-Kanagegh active fault system.

In general, we assume that methane-rich gas emissions found in the NE part of Lake Sevan, associated with the PSSF, have a diagenetic origin, judging by the $\delta^{13} \mathrm{C}_{\text {in }} \mathrm{CH}_{4}$, and are not related with deep fluid reservoirs. However, taking into account the concentrated nature of their emissions, it can be assumed that the system of active faults is the pathway of drainage of gases generated by diagenetic alterations in loose Lake Sevan sediments and may indicate activity of PSSF in the lake bottom.

The studied gases are contrasted by gas emissions of the SW shore of the lake, which mark the extension of the Noratus-Kanagegh Fault. In terms of their geochemical characteristics, they can be considered analogues of $\mathrm{CO}_{2}$ mineral springs, as- sociated with young volcanic centres in the Lake Sevan Basin. Carbon dioxide of the SW shore is of volcanic or mixed volcanogenic-metamorphic origin. It is also accompanied by nitrogen with lower $\delta^{15} \mathrm{~N}=-2.3 \%$. Such $\delta^{15} \mathrm{~N}$ values do not exclude the possibility of mantle $\mathrm{N}$ degassing, since $\delta^{15} \mathrm{~N}$ in MORB $=-5 \pm 2 \%$ (Cartigny and Marty, 2013), which ultimately emphasizes the volcanogenic origin of these gases.

The difference between the composition of gas from the NE and SW points of emission can be explained by geological and structural settings. The NE point is situated in the PSSF zone ( $400 \mathrm{~km}$ long), which is the greatest structure of the Lesser Caucasus. On the contrary, the SW point is situated in the $\sim 25 \mathrm{~km}$ long zone of the Noratus-Kanagegh Fault. The latter is on the east slope of the Neogene-Quaternary volcanic highland. The suggested magmatic chamber feeds the groundwater with $\mathrm{CO}_{2}$.

In situ temperature, electrical conductivity, and $\mathrm{pH}$ tracing in the sampling point and its surrounding did not reveal any noticeable anomalies. Therefore, the source water does not significantly differ from the lake water.

\section{CONCLUSIONS}

The existence of the underwater valley of the Gavaraget River shows that the level of Lake Sevan during erosional activity was $\sim 35 \mathrm{~m}$ lower and the shallow Big Sevan did not exist.

The study of the outcrops at the Lake Sevan shoreline allowed the identification of very young lake sediments sandwiched between lava boulders. The similarity of stratigraphic position evidenced in the vicinity of the site indicates (Kara- 
Chemical and isotope compositions of Lake Sevan bottom and nearshore mineral spring gas emissions

\begin{tabular}{|c|c|c|c|c|c|c|c|c|c|c|c|}
\hline Sample \# & $4 \mathrm{~V} / 18$ & $5 \mathrm{~V} / 18$ & $6 \mathrm{~V} / 18$ & Gavar & Lichk & Ttujur & Gridsor & Ahberg & Zod & Dadjur & Atash \\
\hline $\begin{array}{l}\text { Sampling } \\
\text { location }\end{array}$ & $\begin{array}{c}\mathrm{NE} \\
\text { Sevan, } \\
\mathrm{CH}_{4} \text { ema- } \\
\text { nations, } \\
40 \mathrm{~m} \\
\text { depth }\end{array}$ & $\begin{array}{c}\text { SW } \\
\text { Sevan, } \\
\mathrm{CO}_{2} \text { ema- } \\
\text { nations } \\
\text { near } \\
\text { shore }\end{array}$ & $\begin{array}{l}\text { SW Sevan, } \\
\mathrm{CO}_{2} \text { emana- } \\
\text { tions } 150 \mathrm{~m} \\
\text { from the } \\
\text { shore, } 3 \mathrm{~m} \\
\text { depth }\end{array}$ & $\begin{array}{l}\text { mineral } \\
\text { spring }\end{array}$ & borehole & $\begin{array}{l}\text { mineral } \\
\text { spring }\end{array}$ & $\begin{array}{l}\text { mineral } \\
\text { spring }\end{array}$ & $\begin{array}{c}\text { mineral } \\
\text { spring }\end{array}$ & $\begin{array}{c}\text { mineral } \\
\text { spring }\end{array}$ & $\begin{array}{l}\text { mineral } \\
\text { spring }\end{array}$ & $\begin{array}{l}\text { mineral } \\
\text { spring }\end{array}$ \\
\hline $\begin{array}{r}\text { Latitude, } \\
\text { decimal } \\
\text { degrees }\end{array}$ & 40.6137 & 40.2668 & 40.2668 & 40.350184 & 40.168188 & 40.644249 & 40.231511 & 40.5474 & 40.23725 & 39.97829 & 39.9573 \\
\hline $\begin{array}{c}\text { Longitude, } \\
\text { decimal } \\
\text { degrees }\end{array}$ & 45.0206 & 45.2205 & 45.2223 & 45.129894 & 45.247027 & 45.316627 & 45.01076 & 45.27396 & 45.90029 & 45.43084 & 45.14925 \\
\hline $\mathrm{Ar}$ & 0.421 & 0.141 & 0.094 & - & - & 0.114 & 0.989 & 0.077 & 0.878 & 0.614 & 0.072 \\
\hline $\mathrm{He}$ & - & 0.001 & 0.001 & 0.0069 & - & 0.001 & 0.0069 & 0.001 & 0.084 & 0.011 & - \\
\hline $\mathrm{H}_{2}$ & 0.012 & - & - & - & - & - & - & - & - & - & - \\
\hline $\mathrm{O}_{2}$ & - & 0.013 & 0.013 & 0.027 & 0.059 & 0.054 & 0.027 & 0.019 & - & 0.994 & 0.014 \\
\hline $\mathrm{N}_{2}$ & 21.011 & 4.477 & 3.081 & 1.12 & 0.53 & 1.430 & 1.12 & 2.119 & 58.940 & 22.846 & 1.506 \\
\hline $\mathrm{CH}_{4}$ & 75.561 & 0.050 & 0.021 & 0.0026 & 0.00035 & & 0.0026 & 0.011 & 9.347 & - & 0.001 \\
\hline $\mathrm{CO}$ & 0.001 & 0.010 & 0.011 & 0.0011 & 0.00047 & 0.010 & 0.0011 & 0.012 & 0.008 & - & 0.010 \\
\hline $\mathrm{CO}_{2}$ & 2.451 & 95.189 & 95.992 & 98.29 & 99.32 & 98.072 & 98.29 & 97.223 & 30.552 & 75.521 & 98.298 \\
\hline Total [\%] & 99.457 & 99.881 & 99.213 & 99.45 & 99.91 & 99.681 & 99.45 & 99.462 & 99.809 & 99.986 & 99.901 \\
\hline $\begin{array}{c}\delta^{15} \mathrm{~N}\left(\mathrm{~N}_{2}\right) \\
{[\%]}\end{array}$ & -0.6 & -2.3 & -2.3 & -0.3 & -2.6 & -2.0 & -0.3 & -0.7 & 0.1 & -0.1 & -1.3 \\
\hline $\begin{array}{c}\delta^{13} \mathrm{C} \\
\left(\mathrm{CO}_{2}\right) \\
{[\% \circ]}\end{array}$ & -49.1 & -0.9 & -1.4 & -7.2 & -2.9 & -0.7 & -7.2 & -0.5 & -5.4 & +0.1 & +0.2 \\
\hline $\begin{array}{l}\delta^{13} \mathrm{C} \\
\left(\mathrm{C} \mathrm{H}_{4}\right) \\
{[\% \circ]}\end{array}$ & -67.7 & - & - & - & - & - & - & - & - & - & - \\
\hline
\end{tabular}

khanyan et al., 2004) that the upper blocky lava flow can be at most $\sim 3400$ years old.

The Noratus-Kanagegh Fault, bordering Lake Sevan from the SW, is a young active structure principally of normal kinematics. The fault limits the Gavar Horst to the east. The fault affects the Noratus strata sequence. About $42 \mathrm{~m}$ of the fault footwall portion has been sampled for palaeomagnetic study. The lowermost $5 \mathrm{~m}$ of the outcrop (pebble conglomerates) showed reverse magnetic polarity of the Kaena event and the rest $38 \mathrm{~m}$ portion of the sequence has normal magnetic polarity of the upper part of the Gauss epoch (Fig. 3). Thus, the age of the lower part of the sequence is between 3.1 and $2.3 \mathrm{Ma}$.

The upper and post-Gelasian activity of the Noratus-Kanagegh Fault is proven by displacement of the scoria layer of $2.30 \pm 0.15 \mathrm{Ma} \mathrm{K} / \mathrm{Ar}$ age. The fault plane has a listric shape. The fault spatiotemporal activity shows its genetic relation to volcanic activity.

For the first time in the Republic of Armenia, in the framework of scientific project financed by the Committee of Science of RA, in collaboration with CARPS, complex subaqueous studies were carried out in the shallow area of Lake Sevan (Noratus-Kanagegh tectonic fault zone). The results allow us to reveal the relief characteristics, as well as the presence of a tectonic fault below the recent deposits of the lake. Based on spatial distribution of subaqueous sources and emitted gases, an unknown segment of the $8 \mathrm{~km}$ long fault is mapped.

The discovery of the subaqueous segment of the active fault shows the presence of another natural risk of lake tsunami related to a future rupture of the fault.

Detailed geochemical and isotope studies of gas emanations within the segments of PSSF in the NE part of the lake, represented by methane and nitrogen, reveal a diagenetic (biogenic) nature of the methane. In contrary, abundant underwater gas emissions in the SW part of Lake Sevan within the segments on the Noratus-Kanagegh active Fault, represented mostly by carbon dioxide, are of volcanic or mixed volcanogenic-metamorphogenic origin and can be related to unloading of deep fluid systems. The difference between the composition of gas from the NE and SW points of emission is partly explained by geological and structural settings related to the Neogene-Quaternary volcanic activity.

Acknowledgements. We thank Dr. I. Savov, Dr. H. Nazari and anonymous reviewers for their constructive reviews. The CARPS members, particularly its president Claude Tulumjyan, and divers S. Kojoyan and V. Melkonyan are acknowledged for their assistance in underwater research and sampling of gas emanations. V.A. Lebedev (Institute of Geology of Ore Deposits, Petrography, Mineralogy and Geochemistry of the RAS, Russia) is thanked for K/Ar dating, and V.G. Trifonov for his valuable advices. The research was supported by the Committee of Science of Ministry of Education, Science, Culture and Sports of Republic of Armenia (CS MESCS of Armenia) in the framework of the research project 15T-1E041, and by Russian Foundation for Basic Research (RFBR), project 17-05-00727. Parts of the research were supported by ISTC research project \#G-2153. Field campaign, underwater sampling, geochemical and isotope investigations of gas emanations from the active fault zones from the bottom of Lake Sevan were undertaken in the framework of an Armenian-Russian research project jointly funded by CS MESCS of Armenia (\# 18RF-126) and RFBR (\#18-55-05014). 


\section{REFERENCES}

Arutunova, L.L., Tozalakyan, P.V., Avagyan, A.V., 2011. Fauna of Holocene mollusc in the Berdkunk-Hayrivanq sector of the Lake Sevan. Proceedings of the international conference "Biological diversity and conservation problems of the fauna of the Caucasus". September 26-29 Yerevan, Armenia: 54-55.

Asatryan, G., Danelian, T., Sahakyan, L., Person, A., Avagyan, A., Sosson, M., 2010. Evidence of Late Middle Jurassic to lower Cretaceous Tethyan oceanic lithosphere in the Lesser Caucasus based on new palaeontological (radiolarian) dating of the sedimentary cover of Sevan ophiolite (Armenia). Ofioliti, 35: 91-101.

Aslanyan, A.T., Sayadyan, Y.V., 1984. Excursion 010: neotectonics of Armenia. In: Excursions to the Armenian Soviet Socialist Republic. Guide Book for the 27th International Geological Congress (ed. A.T. Aslanian): 53-86.

Avagyan, A., 2001. Estimation des vitesses de déplacement et des périodes de retour des forts séismes sur le système de Faille de Pambak-Sevan-Sunik (Arménie). Segmentation et relations avec l'activité volcanique. Ph.D. thesis, Montpellier II University, France.

Avagyan, A., Sosson, M., Philip, H., Karakhanyan, A., Rolland, Y., Melkonyan, R., Rebai, S., Davtyan, V., 2005. Neogene to Quaternary stress field evolution in Lesser Caucasus and adjacent regions using fault kinematics analysis and volcanic cluster data. Geodinamica Acta, 18: 401-416.

Avagyan, A., Sosson, M., Karakhanyan, A., Philip, H., Rebai, S., Rolland, Y., Melkonyan, R.,Davtyan, V., 2010. Recent tectonic stress evolution in the Lesser Caucasus and adjacent regions. Geological Society Special Publications, 340: 393-408.

Avagyan, A.V., 2013. Aktiv khzvatsqneri merzmakeresayin drsevorumnery shrjaka mijavayrum (in Armenian). Ph.D. thesis, Yerevan.

Avagyan, A.V., 2019. Aktiv khzvatsqneri merzmakerevutain drsevorumnery (in Armenian). NAS RA "Gitutyun" Publishing House, Yerevan,

Balyan, S.P., Boshnagyan, P.S., 1964. Paleogeografiya i gidrogeologiya basseyna ozera Sevan (in Russian). In: Issues of geology of the Caucasus, Yerevan. Publishing House of the Academy of Sciences of the Armenian SSR: 37-48.

Barrier, E., Vrielynck, B., Brouillet, J.-F., Brunet, M.-F., 2018. Palaeotectonic Reconstruction of the Central Tethyan Realm from Late Norian to Piacenzia. Commission for the Geological Map of the World (CGMW 2018).

Cartigny, P., Marty, B., 2013. Nitrogen isotopes and mantle geodynamics: the emergence of life and the atmosphere- crustmantle connection. Elements, 9: 359-366.

Collective of authors, 1978. Katalog verkhnepliotsen chetvertichnikh vulkani Gegamskoy i Vardeniskoy vulkanicheskikh oblastey (in Russian). Yerevan.

Davtyan, V., 2007. Active faults of Armenia: slip rate estimation by GPS, paleoseismological and morpho-structural data. Ph.D. thesis, Montpellier II University, France.

Djrbashyan, R.T., 2013. Hrabxagitutyan himunqnery ev Hayastani noraguyn hrabxakanutiuny (in Armenian). NAS RA "Gitutyun" Publishing house, Yerevan.

Djrbashyan, R.T., Karapetyan, S.R., Mnacakanyan, A.Kh., 2002. Pozdnekollizioniy reolitoviy vulcanizm SV chasti Armyanskogo Nagorya (in Russian). Proceedings of the Geological Institute of Science of the NAS of Georgia, New Series, 117: 63-93.

Gabrielyan, A.A., 1963. Noveyshaya tektonika i seysmichnost Armyanskoy SSR i smezhnikh chastey Antikavkaza (in Russian). Proceedings of the Geological and Geographical Sciences of NAS of Armenian SSR, 16: 63-76.

Galoyan, G., 2008. Etudes petrologiques, geochimiques et geochronologiques des ophiolites du Petit Caucase (Armenie). These de Docteur en Sciences de l'Universite de Nice-Sophia Antipolis.
Homke, S., Verges, J., Van Der Beek, P., Fernandez, M., Saura, E., Babbero, L., Badics, B., Labrin, E., 2010. Insights in the exhumation history of the NW Zagros from bedrock and detrital apatite fission-track analysis: evidence for a long-lived orogeny. Basin Research, 22: 659-680.

Karakhanyan, A., Tozalakyan, P., Grillot, J.C., Philip, H., Melkonyan, R., Paronyan, D., Arakelyan, S., 2001. Tectonic impact on the Lake Sevan environment (Armenia). Environmental Geology, 40: 279-288.

Karakhanyan, A., Jrbashyan, R., Trifonov, V., Philip, H., Arakelian, S., Avagyan, A., Baghdassaryan, H., Davtian, V., Ghoukassyan, Yu., 2003. Volcanic hazards in the region of the Armenian Nuclear Power Plant. Journal of Volcanology and Geothermal Research, 126: 31-62.

Karakhanyan, A., Jrbashyan, R., Trifonov, V., Philip, E., Arakelyan, S., Avagyan, A., Bagdasaryan, A., Davtyan, V., 2004. Aktivniye vulkani i vulkanicheskaya opasnost na teritorii Armyanskogo nagorya i sopredelnikh oblastey (in Russian). Proceedings of the National Academy of Sciences of the Republic of Armenia, 57: 3-24.

Karakhanyan, A., Arakelyan, A., Avagyan, A., Sadoyan, T., 2016. Aspects of the seismotectonics of Armenia: new data and reanalysis. GSA Special Paper, 525: 45-65.

Karakhanyan, A., Tozalakyan, P., Avagyan, A., Alaverdyan, G., 2018. Gas emission in the active fault zone in the Lesser Sevan lake (Armenia). In: 30 years after the Spitak earthquake: experience and Perspectives. International Conference, Abstracts: 47, 3-7.12, Yerevan, Armenia.

Karapetian, K.I., 1965. Vulkani Gegamskogo nagorya (Morfologiya, stroyenie, klassifikatsiya. Svyaz s treschinnoy tektonikoy) (in Russian). NAS IGS of Armenian SSR, Yerevan.

Karapetian, S., Jrbashyan, R., Navasardyan, G., 2011. Geological map of Quaternary volcanic units of Gegham and Vardenis Uplands. Institute of Geological Sciences of Armenia.

Kharazyan, E.X., 2005. Hayastani yerkrabanakan qartez 1:500 000 (in Armenian). Ministry of Nature Protection of RA, Geological Agency.

Korzhenkov, A.M., Avanesian, M.A., Virgino, E., Karakhanyan, A.S., 2014. Seismic convolutions in the Quaternary deposits of Lake Sevan (Armenia). Geology and Geophysics, 55: 56-65.

Milanovsky, E.E., 1952. Noviye danniye o stroyenii neogenovikh i chetvertichnikh otlozheniy basseyna oz. Sevan (in Russian). Proceedings of the Academy of Sciences USSR, Series of Geology, No 4: 110-119.

Milanovsky, E.E., 1953. Geologicheskoye stroyenie i istoriya formirovaniya Sevanskoy vpadini (in Russian). I, II, Funds NAS IGS of Armenian SSR.

Milanovsky, E.E., 1960. Noveyshaya tektonika Sevanskoy vpadini (in Russian). Bulletin of the Moscow Society of Naturalists, Dep. Geology, 35.

Milanovsky, E.E., 1968. Noveyshaya tektonika Kavkaza (in Russian). Moscow, Nedra.

Paffenholtz, K.N., 1946. Seysmotektonika Armenii i prilezhaschikh chastey Malogo Kavkaza (in Russian). Proceedings of the Academy of Sciences of Armenian SSR, Yerevan.

Paffenholtz, K.N., 1948. Geologiya Armenii (in Russian). State Publishing House of Geological Literature Ministry of Geology of the USSR, Moscow.

Philip, H., Avagyan, A., Karakhanyan, A., Ritz, J.-F., Rebai, S., 2001. Estimating slip rates and recurrence intervals for strong earthquakes along an intracontinental fault: example of the Pambak-Sevan-Sunik fault (Armenia). Tectonophysics, 343: 205-232.

Qocharyan, A., Shirinyan, K., 1978. Katalog verkhnepliotsen-chetvertichnikh vulkanov Arm. SSR (in Russian). 2. Publ. House Yerevan. 
Rolland, Y., 2017. Caucasus collisional history: review of data from East Anatolia to West Iran. Gondwana Research, 49: 130-146.

Rolland, Y., Perincek, D., Kaymakci, N., Sosson, M., Barrier, E., Avagyan, A., 2012. Evidence for $\sim 80-75$ Ma subduction jump during Anatolide-Tauride-Armenian block accretion and $\sim 48 \mathrm{Ma}$ Arabia-Eurasia collision in Lesser Caucasus-East Anatolia. Journal of Geodynamics, 56-57: 76-85.

Sahakyan, L., Bosch, D., Sosson, M., Avagyan, A., Galoyan, Gh., Rolland, Y., Bruguier, O., Stepanyan, Zh., Galland, B., Vardanyan, S., 2017. Geochemistry of the Eocene magmatic rocks from the Lesser Caucasus area (Armenia): evidence of a subduction geodynamic environment. Geological Society Special Publications, 428: 73-98.

Sayadyan, Ju.V., 2009. Noveyshaya geologicheskaya istoriya Armenii (in Russian). Ghitutyun, Yerevan.

Shahinyan, H.V., Meliksetian, Kh.B., Lavroushin, V.Y., Navasardyan, G.Kh., Zaqaryan, Sh.S., Gyulnazaryan, Sh.A.,
Aidarkozhina, A., Manycharyan, D.A., Grigoryan, E.S., 2019, Lracvats ev nor tvyalner $\mathrm{HH}$ ev Artsakhi Hanrapetutyan taratsqneri vorosh hanqayin jreri masin (in Armenian). Proceedings National Academy of Sciences of Republic of Armenia, Earth Sciences, 72: 21-56.

Sosson, M., Rolland, Y., Muller, C., Danelian, T., Melkonyan, R., Adamia, S., Kangarli, T., Avagyan, A., Galoyan, G., Mosar, J., 2010. Subductions, obduction and collision in the Lesser Caucasus (Armenia, Azerbaijan, Georgia), new insights. Geological Society Special Publications, 340: 329-352.

Stepanyan, V.A., 1964. Erkrasharjery Haykakan lernashkharhum ev nra merdzakayqum (in Armenian). "Hayastan" Publishing house, Yerevan.

Vardanyants, L.A., 1948.0 proiskhozhdenii ozera Sevan (in Russian). Academy of Science Arm. SSR, Yerevan. 